\title{
Why are banks paying so little UK Corporation Tax?
}

\author{
G Meeks and J G Meeks*
}

May 2014

We are grateful for valuable suggestions and help from Amir Amel-Zadeh, Robin Chatterjee, Jonathan Faasse, Kitty Meeks, Polly Meeks, Helen Miller, David Tweedie, Geoffrey Whittington and an anonymous referee.

*University of Cambridge 
Abstract

This paper explores the dramatic fall in receipts of UK Corporation Tax (UKCT) from banks, and the widening gap between the global corporation tax recorded as payable in banks' financial statements and the UKCT receipts recorded by the tax authorities. It reviews possible explanations, including changes in tax rates, in operating profits, in deductions which reduce taxable profits, and in the share of profit originating in, or recorded in, overseas jurisdictions. It assigns significant roles to tax-deductible asset impairments and to the allocation of profits among different jurisdictions. It suggests reasons why the recovery in banks' global operating profits may not be accompanied by an early sharp recovery in UKCT receipts.

Keywords: banks, corporation tax, asset valuation, overseas profits, tax avoidance

JEL: G2, H3, M4

Policy points

- UK corporation tax from banks has fallen sharply since 2007. At the same time, the global corporation tax recorded as payable in the financial statements of large UK banks has increased.

- Reductions to the statutory UK corporate tax rate contribute little to the explanation of this disparity.

- Impairment of financial assets, notably loans, is a significant part of the story and will continue to depress corporate tax revenues going forward.

- We also find suggestive evidence that a greater share of UK profits have been recorded offshore. The allocation of banks' profits across countries, and the likely development of the value of gains on financial assets, adds uncertainty to UK tax revenue forecasts. 


\section{Introduction}

This paper analyses banks' financial statements to explore two aspects of UK Corporation Tax (UKCT) payments by banks: the sharp fall in payments in recent years, and the growing disparity between, on the one side, HMRC's record of their UKCT receipts from the banking sector, and, on the other, banks' disclosures of their global corporation tax payable in their annual accounts to shareholders.

The financial sector has grown faster than the rest of the UK economy for much of the last one and a half centuries; and in the decade up to the 2007-8 financial crisis real gross value added in the financial sector grew at around 6\% annually, twice the rate for GDP in total (Burgess, 2011). By 2008 the share of GDP accounted for by financial services exceeded $9 \%$ in the UK. This share had in the previous ten years overtaken the corresponding share for the US; and it reached twice that for France, where it was stable, and for Germany, where it was actually declining (Burgess, op.cit.).

This expansion brought benefit to the public finances. As Figure 1 shows, ahead of the crisis the contribution of the banks alone (just part of the financial sector) to total UK Corporation Tax receipts reached $20 \%$ in $2005-6$. However, the banks' contribution then fell to $4 \%$ by $2011-12$. The public finances could ill afford this decline since it follows the massive transfusion of public funds to avert the collapse of the banking sector during the financial crisis, which raised the ratio of government debt to GDP to levels last seen in the aftermath of the Second World War (IFS, 2014) ${ }^{1}$. In absolute terms, total UK Corporation Tax receipts from the banking sector in current prices have declined from $f 7 b n$ in 2005-6 to just $f 1.3 b n$ in 2011-12 and $f 2.3 b n$ in 2012-13 (HMRC, 2013a). As a materiality check, this decline in annual receipts from the banks is roughly equivalent to total annual expenditure on unemployment benefits (Brown and Hood, 2012).

At first sight it might be expected that this decline in UK Corporation Tax receipts from the banking sector would be reflected in a corresponding decline in the corporation tax outlays recorded by UK banks in their financial statements prepared for shareholders. However, whereas in the fiscal year 2011-12 HMRC received $\mathrm{f1.3bn}$ in UKCT from all the banks within their jurisdiction, a single UKheadquartered bank, Barclays, recorded corporation tax in its income statement of almost $f 2 \mathrm{bn}^{2}$. Yet Barclays is just one of some 150 banks on the Financial Service Authority's (FSA) list of banks incorporated in the UK (FSA, 2013), for whom, subject to important exemptions and reliefs explained below, related particularly to banks' overseas activities, the default UKCT base is "all their taxable profits, wherever in the world those profits have come from"(HMRC, 2012b, p.7). And it might be expected that the UKCT from the 150 UK banks would be augmented by receipts from over 150 further, foreign, banks authorised/entitled to accept deposits through a branch in the UK, for whom the default UKCT base is their "taxable profits arising from their UK activities" 3 .

We explore the fall in receipts and the disparities between HMRC data and companies' accounts using the annual reports of six major banks incorporated in the UK. We find that reductions in the UK's Corporation Tax rate had only a small effect on receipts and that changes in banks' operating

\footnotetext{
${ }^{1}$ Public sector net debt including financial sector interventions rose from 43\% to $150 \%$ of GDP between 2007-8 and 2008-9. Excluding the financial sector interventions the recorded increase is 7 percentage points.

${ }^{2}$ f1.93bn for the year ending December, 2011 - a slightly different period from the HMRC data (year ending 5 April 2012).

${ }^{3}$ These figures include all incorporations: some are part of the same group of companies, for example National Westminster Bank and Royal Bank of Scotland are both listed.
} 
income (including gains and losses on holding fair valued assets) had no effect. Increased deductions from taxable profit (including tax-deductible impairments of loans) have been important. We find little evidence that a substantially higher share of UK banks' profits are originating outside the UK, but some suggestive evidence that a higher share of profits are being recorded offshore. We distinguish factors which are likely to be permanent from those which are temporary and discuss forecasts of future revenues. In line with the Office for Budget Responsibility (OBR), we agree that receipts may remain weak in the short run, depressed by the carry forward of tax losses. In the longer term, there is uncertainty about the evolution of (unrealised) capital gains and losses on financial assets, which are recognised as income for tax purposes. A key challenge that emerges is to discover the allocation of taxable profits between jurisdictions, on which banks' disclosures are often opaque.

Our analysis is inevitably incomplete, because it relates to a sample, and because of the limited data disclosed by the banks. The limited disclosure means that a sample cannot be constructed which truly reflects the experience of the whole sector. However, the highly skewed size distribution of banks means that a large proportion of activity is captured in our small sample of major banks: in 2005-7, the 6 banks in our sample reported global corporation tax of $£ 25 \mathrm{bn}$, against total HMRC UKCT receipts from the whole sector of some $\mathrm{f} 21 \mathrm{bn}$ in those three years (see Tables 2 and 3 below). And they span the range of key business models in the sector - national/global, retail/investment, mutual/public listed.

The paper proceeds as follows. Section 2 describes the data. Section 3 analyses the possible explanations for the fall in UK corporate tax receipts. Section 4 discusses the prospects for tax revenues from the banking sector going forwards and a final section summarises and concludes.

\section{Data}

\section{The sample}

The paper reports data for all the banks whose headquarters are in the UK and which are included in The Banker's (2012) ranking of the world's 150 biggest banks by assets. Six banks qualify for inclusion and are profiled in Table 1. Because the UK industry is unusually concentrated, they include three of the ten biggest in the world (HSBC, ranked 3; Barclays, 7; and RBS 8); and the other three are all in the top half of the world 150 (Lloyds, 20; Standard Chartered, 41; Nationwide, 74). Four of them operate across most areas of banking, from retail banking to investment banking to wealth management. The majority of their assets are located in the UK for three of the banks, and overseas for the other three. Three are conventional joint stock companies listed on the Stock Exchange and with dispersed shareholding. Two are listed but, following rescue in the financial crisis, significant portions of their shares are publicly owned: the government owns a large majority of the shares of RBS and a substantial minority of Lloyds. These banks are managed at arm's length from government, through UK Finacial Investments (UKFI, 2014), and have no special tax arrangements. The sixth, Nationwide, is a mutual, and again pays tax on the same basis as its listed peers.

Data have been hand-collected for 48 company-years on components of their income statements and balance sheets - some of the data are contained in notes which are not included in electronic databases. 
The data for individual banks, and aggregates from HMRC, are throughout in current prices. Where banks' annual reports are expressed in US dollars (HSBC, Standard Chartered), they are converted to pounds using average exchange rates for the year from UKFOREX (2013).

\section{Bank profits and taxation}

Banks operating in the UK are taxed on their income net of accounting adjustments and tax adjustments. We return to the treatment of foreign source income below.

Typical components ${ }^{4}$ of gross income include net interest receipts (the difference between interest received on loans and interest paid on borrowing), fees and commission (e.g. receipts for investment banking services to a client acquiring another business), and gains from trading and investment. These latter gains have become significant for some of the banks in our sample; and under modern "fair value" accounting (IASB, 2004) they include, for example, changes in the market value of financial assets "held for trading", whether or not these gains have been realised. To illustrate their significance: the share of such fair valued assets for large banks globally in recent years has risen to $30 \%$ of the average balance sheet (Amel-Zadeh and Meeks, 2014). The gains, and the tax payable on them, will move with prices in financial markets; and debate has raged over whether the use of fair value accounting for these assets has amplified shocks and intensified the financial crisis (e.g. Plantin et al (2008), Barth and Landsmann (2010), Amel-Zadeh and Meeks (2013)). Deducting operating expenses (such as staff costs) from the gross income yields a measure of operating profit.

A number of "accounting" adjustments are then made to arrive at pre-tax profit. In recent years, adjustments relating to the value of financial assets have been particularly significant. Banks' financial statements record a credit impairment charge that represents an estimate of how much the value of outstanding loans a bank expects not to recover (e.g. because a client is insolvent) has increased. Loans typically constitute towards half of the assets in large banks' balance sheets (AmelZadeh and Meeks, 2014) ${ }^{5}$; and so this adjustment is often highly material. ${ }^{6}$ For example, for Barclays in 2011 this deduction from income was close to $f 4$ billion, compared with pre-tax income of towards $\mathrm{f} 6$ billion. Impairment adjustments tend to be counter-cyclical, with fewer impairments when the economy is flourishing, such that the consequent change in corporation tax payments will tend to be pro-cyclical. In the Appendix we discuss 3 other accounting adjustments, including provisions for credit gains and for the redress of mis-selling of banking products, that have been significant in recent years.

Finally, tax adjustments are required to produce taxable profits (see Macdonald and Martin, 2004, for a fuller account). For example, when calculating taxable profit for a year, HMRC allows businesses to set one year's losses against other years' profits (currently back one year and forward

\footnotetext{
${ }^{4}$ Not all the separate items we identify will typically be shown in the standard published income statement: some can only be found in other parts of the annual report including the notes; some are pooled with other data in the published report; and some are contained in the tax computations, which are not published.

${ }^{5}$ These data are for a population which overlaps with our sample and filed FR Y 9C reports to the US Federal reserve.

${ }^{6}$ Impairment adjustments on assets valued at cost are all on the downside: the maximum sum which will ever be recovered from the debtor is specified in the original debt contract. If an earlier impairment has turned out to be excessive, its reversal does, however, add to earnings.
} 
without limit). Loss offsets were significant for our sample of banks following the 2007-8 financial crisis, as we show below. ${ }^{7}$

In their income statement, banks record a tax "accrual" ${ }^{8}$. This is the amount which the company estimates is due in corporation tax in respect of the period, whether or not it is actually paid within the accounting year. The HMRC data discussed above relate instead to actual payments. Under current arrangements payments lag accruals: companies pay by quarterly installments, the first installment becoming due in month 7 of the accounting period. Also, there may be uncertainty at the time of estimation about the amount of tax payable, which may be the subject of discussion with the tax authorities. ${ }^{9}$ These timing differences make precise annual comparison of company and HMRC data hazardous; and in most of the calculations below we aggregate over several years to mitigate the timing discrepancy.

Most of the banks in our sample have substantial operations abroad. As noted above, the default arrangement is that UK Corporation Tax is levied on all "taxable profits, wherever in the world these profits have come from" (HMRC, 2012b, p.7). However, double taxation relief is often available when a subsidiary has already paid tax overseas and owes tax on the same income in the UK. ${ }^{10}$ In addition, since 2009 "overseas dividend income has been largely exempt from UK corporation tax" (Devereux and Loretz, 2011, p.11) and since 2012 the profits of foreign branches of a UK company have been exempt from UK Corporation Tax (Standard Chartered, 2013, p.221, fn. 1). As a result, the UK tax payable by a multinational bank may differ significantly from what it would have been had the business been operating only in the UK (see the discussion below). The published accounts we draw upon consolidate all the subsidiaries of each bank, UK and foreign, as is legally required in the UK when reporting to shareholders. The disclosures in banks' published annual reports reveal very little of the tax affairs in different jurisdictions: this inevitably limits parts of the analysis.

\section{Explaining the fall in UKCT receipts}

We explore five possible explanations for the fall in UKCT receipts. First, is it attributable to the fall in the UK's Corporation Tax rate? Second, is it associated with a fall in the banks' gross income (including gains and losses on holding fair valued assets)? Third, to what extent can it be explained by reductions in taxable profits on account of tax-deductible impairments of loans? Fourth, have more of the banks' profits originated outside the UK, so that the corresponding corporation taxes have been paid to overseas governments? And fifth, have more of the banks' profits originating in the UK actually been recorded in overseas subsidiaries' accounts, so that tax has been paid at local rates to local governments?

\footnotetext{
${ }^{7}$ In many industrial companies tax-deductible capital allowances on assets such as plant and machinery, which are set at a rate that does not always correspond with depreciation rates used for financial reporting, represent an important adjustment. However, for most banks this is not a material consideration: for example, in Barclays' 2012 balance sheet, property, plant and equipment represent less than $1 \%$ of the assets.

${ }^{8}$ In the banks' accounts, and Table 2 below, this accrual does not include a further tax to which UK banks have been subject in recent years: the Bank Levy - see below.

${ }^{9}$ For example, the Public Accounts Committee (2012) discussed an example where Vodafone, had to pay only $£ 1.25 \mathrm{bn}$ in relation to a tax accrual in its own accounts of some $£ 3 \mathrm{bn}$. Estimate from Brooks (2013).

${ }^{10}$ Double tax relief for all corporations (not just banks) was reported by HMRC as f17billion in 2007-8, against total UKCT payable of $£ 48$ billion in that year (HMRC data, reported in Devereux and Loretz (2011, p.55).
} 


\section{Explanation 1: lower corporate tax rate}

Table 2 reports the rates of UK Corporation Tax and the UKCT receipts from the whole banking sector recorded by HMRC for successive tax years. The tax rate had fallen from $30 \%$ in $2005-6$ to $26 \%$ in 2011-12 (and is scheduled to fall further, to $20 \%$, by 2015-16). As noted above, the tax receipts from the banks fell from $f 7 \mathrm{bn}$ in 2005-6 (and a peak of $f 7.3 \mathrm{bn}$ in 2006-7) to $f 1.3 \mathrm{bn}$ in 2011-12. The direct effect of the fall in tax rate necessarily contributes to the explanation of the fall in receipts; but the impact is relatively small: had the 2005-6 tax rate been in force in 2011-12, the tax receipts would ceteris paribus have been $\mathrm{f0.2bn}$ higher, compared with the overall fall in tax receipts from the banks in this period totalling $f 5.7 \mathrm{bn}$. And any indirect effects of the reduced rate might be expected to operate in the opposite direction, encouraging banks to record more of their profits as taxable in the UK rather than overseas. Such indirect effects would make the overall impact of the tax rate changes even smaller than shown in Table 2's static analysis.

\section{Explanation 2: reduced operating profit}

Table 3 provides aggregated data from the global income statements of the six banks. Totals for operating profit for the three calendar years, 2010-12, are compared with those for the three calendar years preceding the financial crisis, 2005-7. Using a three-year accounting period reduces the impact of exceptional items in individual years, of temporary items reversed in subsequent years, or of timing differences which might confuse the comparison of HMRC payments data with company data on tax payable (see above) ${ }^{11}$.

At first sight, the data offer little support to the falling operating profit explanation of the sharp UKCT decline: in current prices, operating profit ${ }^{12}$ of the sample of banks actually increased slightly compared with the pre-crisis boom years - from $f 139 \mathrm{bn}$ to $£ 143 \mathrm{bn}$. At the operating level itself then the profit aggregate has in effect recovered to its pre-crisis leve $\left.\right|^{13}$.

It seems likely that gains on financial assets held at fair (market) value will have made a significant contribution to this recovery in profit. To illustrate with one financial asset, beginning in 2009 the FTSE 100 index of share prices rose over $40 \%$ by the end of our period (December 2012) - to a level close to that recorded at previous cyclical peaks for prices in 2000 and 2007.

\section{Explanation 3: tax-deductible impairments}

Although gross profit will have been increased by gains on those assets in the balance sheet recorded at fair value, losses on another part of the balance sheet - notably loans recorded at cost minus impairment - will have worked in the opposite direction. Whilst the fair value gains will have been driven by the boom in financial markets, the tax-deductible losses on loans will have been swollen as a result of the slump in the real economy which has accompanied that boom in recent

\footnotetext{
${ }^{11}$ Inter-temporal comparisons will still be confused by structural changes within some of the banks - e.g. if a bank in the sample acquires or divests a banking unit, UKCT payable in respect of that unit will (respectively) enter or disappear from the aggregates for our sample.

${ }^{12}$ We calculated this as pre-tax profits with impairments added back. This is to prevent disturbance from irregular items of income or expense such as capital gains on the acquisition of companies, or special insurance claims.

${ }^{13}$ The average GDP deflator for 2010-12 was $14 \%$ above its average for $2005-7$; so although aggregate profits (more than) recovered in current prices they fell a little short of the earlier period in constant prices. Most of the inferences in the rest of this paper relate to ratios, where inflation is not an issue, so current prices are reported throughout.
} 
years. Table 3 shows a very sharp rise in capital losses reflected in impairment figures. Impairment of this category of financial assets in the income statements more than doubled, from $£ 38 \mathrm{bn}$ to $f 89 \mathrm{bn}$. This led to (roughly) a halving of pre-tax profit, from $f 101 \mathrm{bn}$ to $f 54 \mathrm{bn}$. We explore this contributor further below, in relation to the question whether the decline in UKCT is a temporary 'hangover' from the crisis or a more lasting change.

For these aggregates, this decline in pre-tax profits is accompanied by a fall in taxation recorded in the banks' annual accounts for shareholders, but the fall is less than proportionate: taxation as a share of aggregate pre-tax profits actually rises from $25 \%$ in $2005-7$ to $35 \%$ in $2010-12$. Initially this seems puzzling, since - as we noted above - the rate of Corporation Tax charged by HMRC fell during this period. This puzzle is partly explained by the fact that two of the six banks made losses in some of the recent years; and our aggregation of pre-tax profits in Table 3 has offset these losses against the profits of the other banks, thus understating the actual tax base. Table 4 disentangles the losses and profits since the crisis (before 2008 all the banks were in profit). It shows that the profitable banks assigned $30 \%$ of their pre-tax profit to taxation in their income statements in 2010-12, less than the unadjusted share of $35 \%$, but still, surprisingly, above the earlier figure of $25 \%{ }^{14}$.

\section{Explanations 4 and 5: increased profits originating or recorded overseas}

Part of the explanation of these unexpectedly robust effective tax rates lies in the international operations of the banks. The taxation figures in Tables 3 and 4 are global totals including the profits and tax of the banks' overseas subsidiaries and branches, some of which would be liable to tax at local rates. This consideration may influence the figures in two opposing ways, and perhaps simultaneously. On the one hand, most of the banks in our sample had some operations in jurisdictions with higher tax rates than the UK. As Devereux and Loretz (2011) report, corporation tax rates in most other G20 countries were above those for the UK - two of the largest economies, the USA and Japan, had rates some ten percentage points higher than the UK. If the share of the banks' profits from these economies rose, this would drive the banks' global rate up ${ }^{15}$. On the other hand, Devereux et al (2004) ${ }^{16}$ had raised the prospect in 2004 that financial services might in future "manage to avoid more tax". The motives, opportunities and means to avoid tax increased after the crisis. Admati and Hellwig (2013, p.120ff.) describe the strong motives for banks to restore post-tax earnings after the crisis: other things equal, reducing the share of income paid in tax would mitigate downward pressure on the return on equity - prominently used to measure and motivate

\footnotetext{
${ }^{14}$ The share was much smaller at the height of the banking crisis in 2008-9.

${ }^{15}$ Another possible part of the explanation of the high global tax rate also arises from international operations, and is an extension of the adjustment we made in Table 4. There we argued that the aggregates had misleadingly offset the losses of one bank against the profits of another when calculating the sector's taxable profit. A corresponding effect may be operating within banks: the consolidated accounts provided to shareholders offset one subsidiary's losses against another's profits. But, for example, the German tax authorities will not typically offset the losses of a bank's US subsidiary against the profits of its German subsidiary when calculating the latter's German tax. Our figure for aggregate taxable income may therefore be downward biased (and the consequent tax rate inflated), but the banks' annual reports do not disclose information which would allow us to quantify this. Suggestive evidence that this may be a material factor is cited below: Barclays $(2013$, p.147) report that substantial parts of their tax losses were located in Spain and the US, countries which suffered a more severe decline in property values, and hence in recovery of bank loans, than the UK.

${ }^{16}$ In a paper whose title, 'Why has the UKCT raised so much revenue?', we adapt for the present paper.
} 
executives' performance - and also help meet bank regulators' demands for greater "cushions" of equity capital following the financial crisis. And we discuss below the new opportunities for avoiding UKCT created after 2008 by government tax policy (Gammie et al, 2008, HMTreasury, 2012). As for means of avoidance, ActionAid (2011) report the number of subsidiaries in tax havens owned by UK companies, and UK banks in our sample occupy four of the top ten places in that list; and Brooks (2013) explores the tax avoidance schemes available, with examples from the banking sector. If profits were shifted from the UK to tax havens (e.g. through transfer pricing), then this would reduce the banks' global tax rate.

For this study the issue is why surprising resilience in the global tax rate evident in the accounts did not translate into stability in UKCT receipts. Table 5 explores the share of the global total payable to the UK Exchequer. This exercise is restricted because two of the six banks have in the most recent years not been clearly disclosing the UK component of their taxation total, so the table reports only data for the other four. For these four banks, UKCT represented $30 \%$ of the global taxation they reported in their income statements in the pre-crisis years, 2005-7. But in the most recent threeyear period, 2010-12, this had fallen to just $11 \%$. Global taxation had even increased very slightly, to almost $f 13 \mathrm{bn}$, compared with the three years at the top of the boom. But the element assigned to the UK Exchequer fell from almost $£ 4 b n$ to $£ 1.4 b n$.

Does this declining UK share reflect larger profits originating overseas (resulting from a shift of assets overseas, or higher returns on overseas assets than on those held in the UK), or more generous tax exemptions by HMRC, or a tax-avoiding shift of profits which originated in the UK but have been reclassified as overseas? In the early part of the period some of the banks were declaring their policy to raise the share of overseas activity (e.g. Goodwin (2006), Varley (2006)). The data in the banks' annual reports allow only very incomplete discussion of such shifts. Table 6 presents some evidence, although even this evidence has to be hedged with significant qualifications noted in the Table. In particular, two of the banks' analyses of geographical segments pooled the UK with certain other countries, and we do not know whether the UK held its own in these regional totals. So the conclusions should not be interpreted too precisely. The Table addresses the question whether the banks' assets held overseas were growing faster than those held in the UK (total assets were indeed growing). It reports the share of the UK in these total assets for 2005 and 2012. Whether equal weights or value weights are used in the combination the result is similar: the UK's share on average did not decline - it actually rose by a couple of percentage points over the seven years. At first sight then, and subject to the significant qualifications about the data, we do not find an explanation for the UK's falling share of tax in a falling UK share in the banks' activities.

We would have liked to make a similar comparison for profits. But in addition to the significant data problems already facing the asset calculations, there is the extra difficulty that the banks' published income data by geographical segment do not use consistent income measures. For example, one reports "top line" income before deducting operating expenses and impairment, others report income after making those deductions. We cannot therefore compare like-with-like across banks. We have calculated like-with-like ratios of UK income to total income for each bank across time (for 2005 and 2012), using whatever income measure was available. The average level of these ratios across banks for one year is not a useful number, but comparing the average for 2005 and 2012 does give some indication of the trend in the share of UK income in the global total. This measure (equal- 
weighted) did indeed decline, by 12 percentage points, from $62 \%$ to $50 \%$, over these seven years; but this fall is nothing like so steep as that in the UK's share of taxation.

The available data are too coarse and inconsistent to allow a conclusive analysis of this issue. However, the literature does point to some features of UK arrangements which might also contribute to UK taxation falling faster than the banks' UK activities and income. As already mentioned, the UK government chose to introduce exemptions from tax for some components of overseas income. Some of these will have had a direct effect in reducing UKCT; while some created opportunities for tax avoidance, for example, through international appropriations of profit as dividends. Such opportunities may also have arisen from a relatively "generous" approach to the international allocation of interest payments against income in different jurisdictions.

Gammie et al (2008) discuss the introduction from 2009 of an exemption from UK Corporation Tax for dividends received from foreign subsidiaries of UK companies, in place of the previous system which taxed those dividends after having given a credit for any foreign tax paid on them. Clearly this exemption could directly reduce UKCT payments, but our data do not allow us to measure the effect. However, Gammie et al report, "evidence suggests that the [UK] exchequer would not lose a large amount of revenue"; they illustrate with a case where, before the exemption was introduced, "it seems likely that the UK exchequer also collects very little net tax on the foreign income of UK multinationals" (p.256). But they emphasise the possible indirect effects: "The concern is that taxable income would move offshore": they explain that the exemption "introduces an incentive for investors to move financial assets abroad to countries with a lower corporation tax rate, then to repatriate the returns as tax-free dividends and so benefit from a lower foreign tax rate" (p.249).

From 2012 the exemption was extended to include also foreign branches, a change expected to benefit the banking and insurance industries in particular. The Treasury estimated that the direct effect would be to reduce the UK tax bill of all the affected industries by $f 100 \mathrm{~m}$ p.a. (HMTreasury, 2012). How significant is this in the explanation of falling UKCT from the banks? Table 5 reported that for just the subsample of four UK banks for which suitable data were available, the decline in annual UKCT in our period was around $£ 800$ million $^{17}$. These four banks are likely to have benefitted from only a minor portion of the $f 100$ million relief afforded to all industries, including both banking and insurance - not immaterial, but likely to be significantly less than $10 \%$ of the fall we are trying to explain. Again, however, there could be indirect effects from banks changing their behaviour in the light of the new rules, so as to avoid UK tax.

In relation to the international allocation of interest payments, the Permanent Secretary for Tax at HMRC observed that "The UK is regarded as having a relatively generous regime for interest relief" (PAC, 2008). It is argued that businesses might use this generosity to avoid tax - borrowing in the UK to fund activity, and generate profit, in a country with a lower CT rate, and setting the interest on the loan against the profit from other activities in the UK, gaining relief at a higher CT rate. In their studies of tax avoidance, the Public Accounts Committee describe a variant of this device where "...there is an inter-company loan between [one] Starbucks business and the UK Starbucks business ... with the interest rate set at a higher rate than any similar loan we have seen" (PAC, 2012). The high interest charged to the UK business reduces the UK tax bill.

${ }^{17} £ 1268 m$ p.a. average in 2005-7 (3 year total $£ 3804 m$ ); $£ 467 m$ p.a. in $2010-12$ (total $£ 1402$ ). 


\section{Prospects for future tax payments from bank profits}

\section{Forecasting UKCT}

The Office for Budget Responsibility (OBR) has to forecast financial sector profits in order to estimate UK Corporation Tax from the sector. Their estimates relate to the whole of the financial sector, ours to just a subset of the banking sub-sector. Nevertheless, our analysis is consistent with theirs in important respects; but we would add some extensions and caveats.

OBR (2013) "forecast financial sector profits to remain weak [in 2013] and in 2014". They refer to the "effect of provisions for mis-selling and likely conduct fines" (p.91): we agree that they are likely to be material only in the short-term (see Appendix). And in our discussion of provisioning below we suggest reasons why such provisions might be exaggerated, so that part of them may be reversed later.

In the longer term, OBR expect financial sector profits to grow more slowly than non-financial profits, only in line with nominal GDP. Parts of bank profits, relating to routine lending and to fees on transactions, will indeed be related to activity levels in the wider economy. And although demand for banking services has historically tended to rise faster than aggregate demand (Burgess, 2011), OBR take account also of "the ongoing pressure of regulatory changes"(p.91). Prudential regulation is indeed restricting profit growth, as banks adjust to higher regulatory capital-asset ratios by cutting back on lending (Amel-Zadeh and Meeks, 2013). This tendency to retrench, which has aroused concern among borrowers and government (Chan, 2014), is also driven by banks' own changed appetite for risk following the financial crisis (Admati and Hellwig, 2013).

One element of our analysis which is touched on by OBR is the component of bank profits related not to activity levels but to their holdings of financial assets, and the gains and losses on those assets. As we explained above, a significant part of banks' assets is now recorded at market value ("fair value", "marked to market") rather than at cost, with many of the resulting capital gains and losses recognised in bank income, even when they are unrealised. And as we previously mentioned, the share of bank balance sheets which is recorded at fair value has been increasing and is approaching half of the assets of large banks globally. In our discussion of profit we suggested that such capital gains resulting from the rise in financial markets in the years 2009-12 were likely to be responsible for a substantial part of the recovery in bank profits. To the extent that the rise in the financial markets was the result of quantitative easing (Joyce at al, 2011), that source of bank profit may disappear as monetary policy is tightened. If markets fall, it may be replaced by losses. So in this respect, assuming that bank profits will keep pace with nominal GDP in the longer term may err on the upside.

On the other hand our analysis above did point to a significant factor which might at first sight seem to tend in the opposite direction. And when translating their profit forecasts for the financial sector into projected CT receipts, OBR are in agreement with our emphasis on past losses on the other major component of banks' balance sheets, loans held to maturity. To help identify the impact of these impairments, and predict them for the future, Table 7 shows global impairment figures aggregated for the 6 banks on an annual basis. There is a pronounced cycle, peaking in 2009 in the 
wake of the financial crisis, and returning towards pre-crisis levels more recently. So it might seem that this contributor to squeezed UKCT receipts should be disappearing, and taxable profits recovering.

There is one complication, however, which means that the 'hangover' - arising from the downward revaluation of such financial assets - will last considerably longer. Taxable profits after deducting these impairments were negative in some of the company-years - at least in some of the jurisdictions in which banks operated - following the crisis. So the banks concerned were able to carry forward tax losses to offset against future profits. OBR draw attention to the "high level of losses being carried forward and used against taxable profits" (p.108). And, in contrast with many carry-forward arrangements in personal taxation, the banks can carry them forward indefinitely. Tax bills will be reduced in future years until these deferred tax assets are exhausted. The tax losses carried forward in the balance sheets of the six banks as at the end of 2012 sum to $f 12.6 \mathrm{bn}$, having risen from $f 1.8 \mathrm{bn}$ at the end of 2007. Using for illustration the planned UKCT rate from 2014, this would mean that $f 57$ billion of future profits would be free of tax: for comparison, the aggregate pre-tax profits of the 6 banks for the three years 2010-12 were f54billion (Table 3). We do not know what proportion of the carried forward losses can be set against UK profits rather than those earned overseas; and it will be a significant matter: for example, Barclays' 2012 Accounts report that a substantial part of their tax losses are located in the US and Spain (Barclays, 2013, p.147).

The eventual out-turn remains unclear. And a further, but lesser, caveat over the impact of tax losses carried forward arises from the literature on "creative" accounting. That literature suggests that for new CEOs there will be incentives to incorporate in the accounts over-pessimistic provisions and impairments, particularly at times of crisis (Meeks and Meeks, 2013). This "big bath" behaviour depresses the profits associated with the predecessor CEO, setting a conveniently low benchmark for the new CEO; and, if, say, the impairment provision proves too big - debts deemed bad are actually paid - then the new CEO gains a boost to profit on her watch when the impairment is reversed. In the case of several of the banks in our sample, the typical triggers for a big bath were very powerful: the banks were in crisis and the outgoing CEOs were vilified on their departure; moreover, auditors who had perhaps been thought uncritical during the boom would have welcomed extra caution and "prudence" on their clients' part in the aftermath. So it could be that the provisions for mis-selling and penalties, and the impairments of financial assets such as loans, turn out not to be warranted in full, and reversals will add somewhat to future profit and CT payments.

What is clear is that the biggest difficulty in using company accounts to help forecast UKCT is the paucity of data disclosed on the distribution of profits and of tax between national jurisdictions. Table 8 reports annual data for the 4 banks which made clear their UKCT. This shows again, as we reported above, that the share of UKCT in the banks' global tax accrual has fallen sharply, even though their UK assets have not diminished and their UK income appears to have fallen only somewhat; Table 8 shows also that the year to year fluctuations of the global and the UK figures bear scant relation to one another. The banks' disclosures often provide little guidance on what lies behind these divergent movements. We return to the issue of disclosure below.

\section{2. ii. Forecasting related taxes}

a.Bank levy 
More recently, the banking sector has been subject to a further UK tax alongside UKCT. The Bank Levy effective from 2011-12 was introduced to "ensure that the banks make a full and fair contribution ... in respect of the potential risks they pose to the UK financial system and wider economy"(Hoban, 2010). In contrast with the profits base of Corporation Tax, it is levied on the balance sheet (equity and borrowing, with a higher rate for short-term than for long-term borrowing). It applies to the global balance sheets of larger UK banks and to the UK operations of banks from other countries.

In contrast with Corporation Tax a bank will not escape the levy when it makes losses, or when activities are switched abroad (unless it shifts headquarters), or if profits are transferred abroad. It is linked to proposals by the IMF (2010), as an accompaniment to international prudential regulation, which aimed to secure international harmonisation of levy rates, and so to be neutral with respect to location decisions. It was intended that it would "generate around $£ 2.5$ billion of annual revenues" (Hoban, 2010). However, HMRC (2013a) report that receipts of Bank Levy totalled f1.6billion 201213 , the first full year of operation, compared with $f 2$.3billion in UK Corporation Tax from banks: the yield of the Bank Levy has turned out to be substantially less than was expected.

b.Income tax on dividends paid to shareholders

The international allocation of corporation tax referred to earlier has implications also for another source of government revenue, income tax on dividends. If profits are transferred overseas in order to avoid UKCT, then the loss of revenue for the Exchequer is more significant under current UK arrangements for taxing dividends than it would be currently in some other jurisdictions, or would have been previously in the UK. UK shareholders are credited for tax which is deemed to have already been paid by the company on the profits which are being distributed to shareholders. Table 9 suggests that in an extreme case, where all the 2010-12 dividends of the sub-sample of banks went to UK taxpayers, those taxpayers would have been exempt from $\mathrm{f} 1.1$ billion of UK income tax, even if the profits were recorded overseas, and all the corporation tax was paid overseas. By contrast, under the dividend imputation/franking system of Australia and New Zealand, shareholders are only given credit for the domestic corporation tax that has been paid - if a local company has not paid local corporation tax, then shareholders are liable for income tax at the full amount on dividends received (New Zealand Treasury (2008)). Again, as Brooks (2013) explains, up to 1999 in the UK, Advance Corporation Tax (ACT) levied a percentage of the distribution when dividends were paid to shareholders regardless of their origin; and this was then set off against the company's final UKCT bill. The $£ 1.1$ billion in our hypothetical example would under ACT arrangements have represented a floor for the UK Exchequer's combined tax take from the banks and their shareholders if ACT were still in place; whereas under present arrangements UK shareholders would retain their full tax relief on dividends even if all profits were shifted overseas and no UKCT was paid.

\section{Concluding summary and comments}

\section{The record}

Our analysis has ruled out some of the most obvious possible reasons for the decline in receipts of UKCT from banks, but leaves some mystery over the full explanation. We have concluded that changes in tax rates contribute little to the explanation of the reduced tax take - less than $4 \%$ of the 
decline from 2005-6. Changes in global operating profits contribute nothing at all: in the latest three years of our study operating profits had actually recovered to their pre-crisis levels (in current prices). It is likely that these profits were boosted significantly by holding gains on assets marked to financial markets which were rising thanks to quantitative easing. On the other hand, global pre-tax profit was halved from its pre-crisis level just by the costs of impairing financial assets such as loans. But although this is a significant factor, the figures show this is far from the full story. For our subsample of banks with better disclosure, global taxation is no smaller in the last three years than before the crisis, but the UK's share of the total tax in the income statements has fallen from $30 \%$ to $11 \%$. This is not because these banks now rely for much more of their business on overseas subsidiaries: the UK's share of the global assets held by the banks appears to have been relatively stable. And nor does it seem - though here the evidence is only suggestive - that the UK's share of profit has fallen anything like so fast as its share of corporation tax. During our period the government has deliberately exempted some components of overseas income from UK taxation ${ }^{18}$. This has also created new opportunities for tax avoidance; and HMRC describe the UK regime as "relatively generous" compared with other jurisdictions in its treatment of some deductions for tax purposes. The pattern we observe is consistent with increased and significant tax avoidance, as Devereux et al (2004) conjectured might happen. But sufficient data are not disclosed in the accounts for us to quantify this contribution to falling UKCT receipts.

\section{The prospects for future UKCT payments by banks}

We have outlined factors which support the OBR view that the banking sector is unlikely to achieve sustained profits growth at a faster rate than the rest of the economy as it did before the crisis. We explore the capital losses mentioned by OBR and provide some quantification. The new impairment losses on, for example, loans, which have been so important following the crisis, should decline as macro-economic conditions improve; but the tax losses carried forward as a result of such impairments in the past could relieve the equivalent of three years' of future profits from any tax. At the same time, many banks' operating profits are increasingly dependent on unrealised gains (and losses) on those financial assets held at fair (market) value. This portion of profits, which has been swollen by the recovery of financial markets after the crash, will depend on the vagaries of prices in financial markets rather than the underlying economy; and these in turn are influenced by monetary policy, notably quantitative easing, which the authorities plan to withdraw.

Perhaps the greatest challenge in forecasting banks' UKCT is to understand the allocation of taxation between jurisdictions when banks' disclosures on this matter in their annual reports are often patchy or opaque. This reticence persists in spite of the fact that Section 393 of the Companies Act 2006 requires that the directors of a company must not approve accounts unless they are satisfied they give a "true and fair view". And the Financial Reporting Council (2011) insist that "professional judgement is all important", for example in "giving appropriate disclosures even where not specifically required by accounting standards" (p.2). Two of our sample of six banks in the more recent years did not even clearly disclose their UKCT. An example from outside the banking sector of good practice in aiding forecasting and UK fiscal planning is provided by Vodafone, which has

\footnotetext{
${ }^{18}$ If the new exemptions had been part of a concerted multilateral programme to focus taxation on the countries where profits originate, then, alongside reductions in UKCT from banks headquartered in the UK but active overseas, it might have been expected to raise the UKCT yield from the 150 overseas banks operating in the UK. At first sight the collapsing UK aggregate tax receipts we reported above do not seem to reflect such a change.
} 
recently chosen to disclose its tax payments in each of the jurisdictions in which it operates (Houlder, 2013). This contrasts with the general position: HMRC's Permanent Secretary for Tax has voiced concern over the incomplete disclosures in relation to the international distribution of corporations' tax payments (PAC, 2008, p.57). And in this context the Public Accounts Committee $(2008$, p.58) has expressed puzzlement that the confidentiality accorded to individuals' tax affairs is extended to public companies listed on the Stock Exchange. Just as the incomplete disclosures have hampered our efforts, they must constrain the OBR's ability to forecast the tax revenues which are needed to repay the extraordinary government borrowing used to bail out the banking system. Similarly they must hinder the shareholders of the banks in forming their expectations of future earnings - to the detriment of capital market efficiency ${ }^{\underline{19}}$.

\section{Postscript}

As this paper went to press, Barclays (2014) made a helpful step change in their tax and other disclosures, releasing data by country on their corporation tax payments. UKCT for 2013 totalled $\mathrm{f53 \textrm {m }}$, and global CT $\mathrm{f} 830 \mathrm{~m}$ (the corresponding figures for the start of our period, 2005, were f961m and $f 1439 \mathrm{~m}$ respectively).

\section{References}

ActionAid (2011), 'Footsie 100 Tax Haven Tracker', http://www.actionaid.org.uk/tax-justice/ftse100-tax-haven-tracker

Admati, A. and Hellwig, M. (2013), The Bankers' New Clothes, Princeton, N.J.: Princeton University Press

Amel-Zadeh, A. and Meeks, G. (2013), 'Bank failure, mark-to-market and the financial crisis', Abacus, 49: 308-339

Amel-Zadeh, A. and Meeks, G. (2014), 'Fair value and the Great Financial Crisis', in Jones, S., ed. The Routledge Companion to Financial Accounting, Routledge, forthcoming

Auerbach, A., Devereux, M., and Simpson, H., 'Taxing corporate income', in Mirrlees, J., Adam, S., Besley, T., Blundell, R., Bond, S., Chote, R., Gammie, M., Johnson, P., Myles, G. and Poterba, J., (2011) Tax by Design: the Mirrlees Review, Oxford: Oxford University Press

Barclays (2013), Annual Report and Accounts, 2012

Barclays (2014), Country Snapshot, 30 June, 2014, http://www.barclays.com/country-snapshot

\footnotetext{
${ }^{19}$ As this paper went to press, Barclays (2014) made a helpful step change in their tax and other disclosures, releasing data by country on their corporation tax payments. Corporation tax payments in the UK for 2013 were $f 53 \mathrm{~m}$, and globally $£ 830 \mathrm{~m}$. These numbers were actual payments during the year, rather than the figures in the income statement, which represent the taxation payable in respect of the year's activities, some of which will typically be paid in subsequent years. The amounts provided for global corporation tax in the income statements were $f 1,571 \mathrm{~m}$ in 2013, $£ 616 \mathrm{~m}$ in 2012, and $£ 1902 \mathrm{~m}$ in 2011. We have explored above some of the main reasons for these large fluctuations, including the impairment of financial assets and provisions for redress. At the start of our period in 2005, when Barclays still disclosed UK figures, UKCT payable was $67 \%$ of the $f 1439 \mathrm{~m}$ corporation tax payable globally. The recent disclosures for 2013 payments show the UK share as $6 \%$ of the global total.
} 
Barth, M. and Landsman (2010), 'How did financial reporting contribute to the financial crisis?' European Accounting Review, 19: 399-423

Brooks, R. (2013), The Great Tax Robbery, London: Oneworld

Browne, J. and Hood, A. (2012), A Survey of the UK Benefits System: IFS Briefing Note BN13, London: Institute for Fiscal Studies

Burgess, S. (2011), 'Measuring financial sector output and its contribution to UK GDP', Bank of England Quarterly Bulletin, 2011, Q3: 234-246

Chan, S.P. (2014) 'Lack of business lending in the UK', http://www.telegraph.co.uk/finance/newsbysector/banksandfinance/10576623/Vince-Cable

Devereux, M., Griffith, R. and Klemm, A. (2004), 'Why has the UK Corporation Tax raised so much revenue?' Fiscal Studies, 25: 367-88

Devereux, M. and Loretz, S. (2011), Corporation Tax in the United Kingdom, Oxford: Centre for Business Taxation

Financial Reporting Council (2011), True and Fair, London: Financial Reporting Council, www.frc.org.uk

Financial Services Authority (2013), 'List of banks - 2013', http://www.fsa.gov.uk/pages/library/other publications/index.shtml

Gammie, M., R.Griffith and H.Miller (2008), 'Taxation of companies' foreign profits', chapter 12 of The IFS Green Budget January 2008, The Institute for Fiscal Studies, http://www.ifs.org.uk/budgets/gb2008/index.php

Goodwin, F. (2006), http://news.bbc.co.uk/1/hi/business/4757618.stm

HMRC (2012a), 'Pay-as-you-earn and corporate tax receipts from the banking sector', August 2012, http://www.hmrc.gov.uk/statistics/banking.htm

HMRC (2012b), Corporation tax statistics', October 2012, http://www.hmrc.gov.uk/stats/corporate tax/menu.htm

HMRC (2013a), 'Pay-as-you-earn and corporate tax receipts from the banking sector', August 2013, http://www.hmrc.gov.uk/statistics/banking.htm

HMRC (2013b), Corporation tax statistics', 31 October 2013, http://www.hmrc.gov.uk/stats/corporate tax/menu.html

HMRC (2013c), 'Tax on UK dividends', http://www.hmrc.gov.uk/taxon/uk.htm HMTreasury (2012), 'Taxation of foreign branches', http://www.hmrc.gov.uk/budgetupdates/autumn-tax/tiin1030.pdf 
Hoban (2010), Bank Levy: consultation, HM Treasury, HMRC,

https://www.gov.uk/government/uploads/system/uploads/attachment data/file/81257/consult ba nk levy condoc.pdf

Houlder, V. (2013), 'Tax outcry spurs shift in attitude', Financial Times, 8 June, 2013

IFS (2014), Fiscal Facts, http://www.ifs.org.uk/fiscalfacts/fiscalaggregates

International Accounting Standards Board. (2004) IAS 39 Financial Instruments: Recognition and Measurement, London: IASB

IMF (2010), A Fair and Substantial Contribution by the Financial Sector: Final Report for the G-20 Joyce, M., Tong, M. and Woods, R. (2011), 'The United Kingdom's quantitative easing policy: design, operation and impact', Bank of England Quarterly Bulletin, 51, 3: 200-212

Macdonald, G. and Martin, D. (2004), 'Aligning tax and accounting profits: the need to review current legislation', Institute for Fiscal Studies, TLRC Discussion Paper No. 5

Meeks, G. and Meeks, J.G. (2013) 'Mergers, accountants and economic efficiency', http://ssrn.com/abstract=2372028

New Zealand Treasury (2008)

http://www.treasury.govt.nz/publications/informationreleases/australiasfuturetaxsystem/mrfcnzicaftr-oct08.pdf

OBR (2013), Office for Budget Responsibility. Economic and Fiscal Outlook, December 2013

PAC (2008), House of Commons Public Accounts Committee, Oral evidence to the PAC on 28 January 2008 ,

http://www.publications.parliament.uk/pa/cm201012/cmselect/cmpubacc/1531

PAC (2012), House of Commons Public Accounts Committee, Tax avoidance by multinational companies, http://www.publications.parliament.uk/pa/cm201213/cmselect/cmpubacc/716/71605

Plantin, G., Sapra, H. And Shin, H. (2008), 'Marking-to-market: Panacea or Pandora's Box?, Journal of Accounting Research, 46: 435-460

Standard Chartered (2013), Annual Report and Accounts, 2012

The Banker (2012), 'Top 150 banks worldwide ranked by asset size', The Banker, July 2012

UKFI (2014), UK Financial Investments Ltd., http://www.ukfi.co.uk

UKFOREX (2013), 'Yearly average rates: British Pound: US Dollar', http://www.ukforex.co.uk

Varley, J. (2006), 'Remarks', presented at the Merrill Lynch Banking and Insurance CEO Conference, 3.10.2006. 
Figure 1. Corporation Tax receipts from the banking sector as a percentage of total UK Corporation Tax receipts

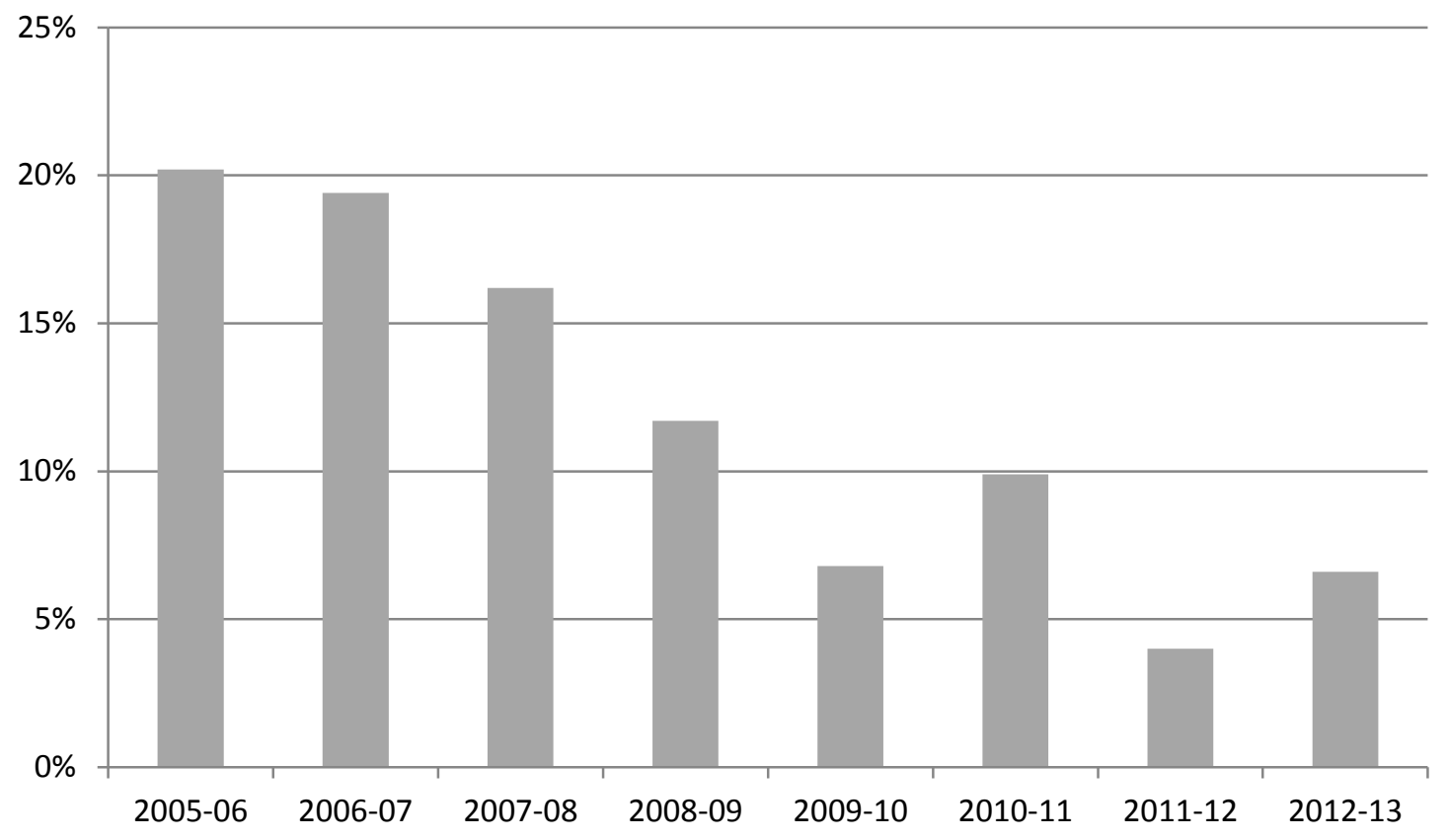

Source: HMRC, 2013a, 2013b 
Table 1 Profile of banks in the sample

\begin{tabular}{|c|c|c|c|c|c|c|c|}
\hline Bank & Global & & Sectors(ii) & & Ownerst & & Majority \\
\hline & Rank(i) & Retail & Investment & Wealth & UK govern- & Mutual & location(iv) \\
\hline & & & & Mgt. & ment \% (iii) & & \\
\hline Barclays & 7 & $*$ & $*$ & * & & & overseas \\
\hline $\mathrm{HSBC}$ & 3 & $*$ & $*$ & $*$ & & & overseas \\
\hline Lloyds & 20 & $*$ & & $*$ & 33 & & UK \\
\hline Nationwide & 74 & $*$ & & & & $*$ & UK \\
\hline RBS & 8 & $*$ & * & $*$ & 81 & & UK \\
\hline Standard Ch'd & 41 & $*$ & * & $*$ & & & overseas \\
\hline
\end{tabular}

Notes:

* active in this sector

i.By assets (The Banker, 2012)

ii.The segmental data disclosed by businesses in their annual reports is not standardised: these sectors do not correspond to the diverse categories used by different banks, and are not exhaustive allocations - for example, some banks have substantial insurance operations. These allocations are therefore only suggestive.

iii. As at December 2013. http://www.ukfi.co.uk

iv.By assets

Table 2 Corporation tax rates and actual and counterfactual tax receipts from the banking sector

UKCT rate Actual HMRC receipts
Receipts with tax rate
unchanged from $30 \%$

$\begin{array}{llcc} & \% & f b n & f b n \\ 2005-6 & 30 & 7.0 & 7.0 \\ 2006-7 & 30 & 7.3 & 7.3 \\ 2007-8 & 30 & 6.6 & 6.6 \\ 2008-9 & 28 & 3.9 & 4.2\end{array}$




$\begin{array}{llll}2009-10 & 28 & 2.1 & 2.2 \\ 2010-11 & 28 & 3.5 & 3.7 \\ 2011-12 & 26 & 1.3 & 1.5\end{array}$

Sources: calculated from HMRC (2012a, Table 1), HMRC (2012b, page 7)

Table 3 Aggregated income statement data for the six major UK banks: 2010-12 compared with 2005-7

fbillion

2005-7

2010-12

Gross operating profit

139

143

Impairment

38

89

Pre-tax profit

101

54

Taxation

25

19

Apparent tax rate (\%)

25

35

Sources: Annual Reports and Accounts for Barclays, HSBC, Lloyds, Nationwide, RBS and Standard Chartered. All the banks report profit on a calendar year basis, except for Nationwide which uses the tax year.

Table 4 Disentangling the loss-makers from Table 4's aggregates: the tax rate on just those banks which reported positive pre-tax profit in the year

fbillion

$\begin{array}{lcccc}\text { Year } & \text { Pre-tax } & \text { Tax } & \text { Tax/Profits } & \text { (Losses) } \\ & \text { profits } & & & \\ 2008 & 13.6 & 0.3 & 0.02 & (40.8) \\ 2009 & 13.8 & 0.2 & 0.01 & (2.6) \\ 2010 & 22.8 & 7.1 & 0.31 & (0.2) \\ 2011 & 24.0 & 5.9 & 0.24 & (4.7) \\ 2012 & 17.7 & 6.3 & 0.35 & (5.7)\end{array}$


Source: annual reports and accounts, as for Table 4.

(Losses) are those of the loss-making banks: the profits in column 1 combined with the losses in column 4 equal the aggregated profit for 2010-12in Table 4

\section{Table 5 UK tax and global tax for a subset of 4 banks}

fmillion

Period Global tax UK tax UK/Global tax

$\begin{array}{llll}2005-7 & 12697 & 3804 & 0.30\end{array}$

$\begin{array}{llll}2010-12 & 12972 & 1402 & 0.11\end{array}$

The data exclude Barclays and RBS from the sample of 6 banks reported in Table 4 .

Table 6 Assets held in the UK as a proportion of total assets: averages for the six major banks 20052012

UK assets/total assets

$\begin{array}{lll}\text { Equal weights } & 0.60 & 0.62\end{array}$

$\begin{array}{lll}\text { Value weights } & 0.55 \quad 0.57\end{array}$

Source: annual reports and accounts, as for Table 4

Note

The data for HSBC include in both years not just the UK assets but also those for the rest of Europe; similarly, Standard Chartered pool the UK data with Europe and the Americas. Our calculations implicitly assume that the UK maintained its share of these regional aggregates. In both cases the banks report increases of about 10 percentage points in the share of global assets held in the regions including the UK. The UK share was roughly constant for Barclays, Nationwide and RBS. Lloyds' activities are described as "predominantly in the UK" in 2005. This is included as $100 \%$ UK in the calculations: Lloyds' reported share for 2012 was $89 \%$.

Table 7 Impairment data from the income statements of the six major UK banks

fbillion

20059 


$\begin{array}{ll}2006 & 12 \\ 2007 & 16 \\ 2008 & 32 \\ 2009 & 59 \\ 2010 & 36 \\ 2011 & 31 \\ 2012 & 21\end{array}$

Source : annual reports and accounts, as for Table 4

Note: the annual totals do not sum exactly to the three-year totals in Table 4 because of rounding

Table 8

Annual global and UK taxation: 4 banks

$\begin{array}{llr}\text { fmn } & \text { Global tax } & \text { UK tax } \\ 2005 & 4615 & 1257 \\ 2006 & 4811 & 1047 \\ 2007 & 3271 & 1500 \\ 2008 & 2210 & 1538 \\ 2009 & -523 & 1097 \\ 2010 & 4718 & 263 \\ 2011 & 2802 & 790 \\ 2012 & 5334 & 349\end{array}$

Source: annual reports and accounts, as for Table 6

Table 9 Illustration of the personal tax credit on dividends for the subset of 4 banks

fmillion

Total dividends, 2010-12

11002

Maximum tax credit

1100 
The maximum tax credit was $10 \%$ of the gross dividend

The data exclude Barclays and RBS, as for Table 6 . 


\section{Appendix}

In addition to the credit impairment charges that are discussed in the main text, there are three other accounting adjustments that have been important in recent years.

First, banks will record an (unrealised) "own credit" gain when the market value of the bank's own liabilities falls. Such falls will often reflect a view in the market that the bank is more risky (buyers perceive that the probability of their honouring their debt has fallen).The rationale for recording this as a gain is that, in principle, the bank could buy back at a discount debt whose value has fallen in the market, thereby benefitting shareholders, whose stake is - definitionally - the residual of assets minus liabilities. Own credit gains, and therefore the associated tax payments, tend to be countercyclical. In Barclays' accounts, for example, this own credit gain was $£ 2.7 \mathrm{bn}$ in 2011 , generating a tax charge; and in 2012 the adjustment reversed (its own debt had increased in value on the market), with an own credit loss of $£ 4.5 \mathrm{bn}$, producing a tax credit (Barclays, 2013, p.109). We do not attempt to quantify the "own credit" gains and losses in our analysis. The gains and losses are only temporary and tend quickly to reverse: on redemption the debt will be repaid by the banks at the price originally set in the contract. We assume that own credit gains and losses will roughly cancel one another out over time, only adding noise to the annual figures, and are unlikely to be significant for the multi-year periods we consider.

Second, in recent years, material provisions have been made by a number of UK banks for redress to those clients who have suffered from mis-selling by banks. For example, Barclays made a provision in its 2012 accounts of $£ 1.2 \mathrm{bn}$ for redress in respect of payment protection insurance (PPI) and f0.85bn in respect of interest rate hedging products. ${ }^{20}$. The provisions for mis-selling only appeared at the end of our period and may have been exaggerated. We discuss this in section IV.

Third, some of the banks in our sample also recorded a very substantial impairment of assets, and specifically purchased goodwill, which is the difference between the purchase price of a takeover target and the fair value of its separate assets. This goodwill is impaired when its valuation in the books is no longer warranted by expected future cash flows. RBS included an impairment charge of some $\mathrm{f20bn}$ in its 2008 accounts, principally related to the acquisition of ABN-AMRO. These writedowns have a major impact on earnings attributable to shareholders (in the RBS case it was said to produce the largest ever annual loss in UK corporate history), but in most jurisdictions they have no impact on tax payments: they are not deemed tax-deductible.

\footnotetext{
${ }^{20}$ Barclays (2013, p.109) reports that the own credit gains and losses outlined above together with these provisions generated a tax charge of $£ 0.6 \mathrm{bn}$ in 2011 and a tax credit of $f 1.5 \mathrm{bn}$ in 2012
} 